\title{
From Facilitator to Knowledge-Builder: A New Role for the Teacher of the Future
}

\author{
Elizabeth Hartnell-Young \\ Centre for Applied Educational Research, The University of Melbourne, Victoria 3010, \\ Australia,ehy@results.aust.com
}

\section{BACKGROUND}

The influence of constructivism and the spread of information and communication technologies (ICT) in classrooms are both expected to change the role of the teacher in the classroom from the expert dispensing knowledge to the facilitator of student learning (Dwyer, Ringstaff, \& Sandholtz, 1991; Hadley \& Sheingold, 1993; Ravitz, Becker, \& Wong, 2000). In such a student-centred classroom the teacher is expected to understand individual learning styles and appropriate means to scaffold learning while social constructivism emphasises student collaboration and interaction with the learning context. The notion of the teacher as facilitator in a student-centred classroom may have been useful to progress pedagogical thinking, but limits attempts to create a knowledge-building community which requires social relations to be reconceptualised. Some suggest that the focus should be on learning-centredness (Marzano, 1992) and many teachers using ICT are happy to acknowledge that they are themselves learners rather than experts. Further, economic and educational imperatives, and the frequent complaint that teachers have "no time" now require that teachers engage in a community of practice where their own learning activities are purposeful and authentic because they are situated within their work (Brown \& Campione, 1994; Lave \& Wenger, 1994). This community can include teachers and students as co-learners, while technology as a communication medium opens up the possibility for collaboration within and across schools and with other learning partners locally and internationally. (The terms "learning" and "knowledge-building" are used with similar meaning in this paper.)

The original version of this chapter was revised: The copyright line was incorrect. This has been corrected. The Erratum to this chapter is available at DOI: 10.1007/978-0-387-35701-0_35 
Scardamalia and Bereiter (2002) argue that where a collaborative knowledge-building approach is adopted, the work to be done in schools becomes the construction of collective knowledge and students become participants in a learning organisation. Similarly it seems that teachers working in a learning organisation cannot operate in isolation, but must model collaboration with other teachers as they reflect on and improve their practice and develop new knowledge. As Hargreaves (1999) suggests, the knowledge teachers bring and create should be better managed to help schools realise their intellectual capital. This paper describes some current examples of teachers and students working together in knowledge-building activities in schools.

\section{THE SILT PROJECT}

The Successful Integration of Learning Technology (SILT) Project consists of qualitative studies over two years in 28 selected state primary and secondary schools in Victoria, Australia. One study aimed to identify the roles and behaviours of teachers using computers in the curriculum areas of Science and Study of Society and Environment (SOSE) in order to assist in future professional development. Teachers used computers in classrooms and computer labs and most had a personal laptop computer subsidised by the Department of Education \& Training. Data were gained from conversations with teachers and principals and classroom observations. Transcripts were given to teachers not only for checking but to encourage the documenting of reflective thought. Eight teachers in two primary schools also provided electronic reflective learning journals, which they kept as part of a collaborative classroom project they devised themselves.

Most teachers using computers espoused and implemented a facilitating role in the classroom, generally interacting with individuals and small groups rather than whole classes in both primary and secondary schools. They happily took on the role of learner from, or co-learner with, their students, particularly in relation to learning technical skills, as this teacher describes:

I find it really stimulating that the students then become my teacher, they teach me things and that's what I found very beneficial. That relationship between the teacher as the provider of the information, student as the person who absorbs it or learns it, then that's completely changed. Everyone is just a learner and just engaging in some sort of exchange, which I find excellent and I think probably some of the most interesting things I have learned about using computers, given that I would describe myself as an early novice in the area, have been things that kids have shown me (secondary teacher). 
Some of the teachers in the project had moved beyond the individual facilitator role towards knowledge-building in collaboration with others. These teachers and their students engaged in group-work within the school and communicated with external participants in other schools, industry or the wider community over several weeks. One SOSE class in a city secondary school communicated with a country class to share information about daily life, using email, chat and a face-to-face visit to build up a picture of contrasting environments which was presented on a website. However the potential of this project for knowledge-building was limited as it involved only one teacher in each school. In several schools, teams of teachers and students in Science and SOSE used video conferencing, email and telephone and also engaged in face-to-face interaction to undertake research projects and produce quality products. From planning to realisation, these projects enabled teachers to immerse themselves in continuous professional learning activities as part of their daily work. Two schools using video-conferencing within a mentoring framework for school leaders, teachers and students were able to see the actual operation of classrooms each other's school, stretching their bandwidth capacity to breaking point, but assisting in building a community of practice amongst teachers.

Haslam (2002) found that involvement in these SILT-supported projects gave teachers the confidence to share their learning, an essential aspect of knowledge-building:

I had a great deal of fun as well as professional development doing this, presenting at a conference, videoing my students (secondary teacher).

She also found that students reported enhanced learning outcomes:

We were more focused, interested, it sort of made us stay keen, flat out on this work. Pretty much involved all the time. It was probably [pause] doing it this way sticks in your mind better, seems to, this way we got to get more involved. Like I just remember it better. I read the information and trying to put it down into your own little thing, to explain to others that made it stick in my mind better. It is harder work. Perhaps this is not a bad point (secondary student).

The knowledge-building teachers were facilitators, but they displayed additional characteristics that had developed as part of team or school culture over a period of years. They valued social connectedness between people, talked about learning processes with their colleagues as well as their students, planned activities together, linked curriculum areas, invited others into their classrooms, collaborated with and mentored teachers within and across schools, documented their experience in journals, recorded student activities, collected data in their classrooms, participated in email discussion 
and presented at conferences. The knowledge-building schools were led by principals who displayed leadership in learning and in applications of technology, supported and encouraged the teachers and raised expectations that teachers and students share knowledge. This was modelled from the classroom to a wider scale:

There is an expectation in this classroom that no knowledge is sacred, everyone shares and if someone moves from one group they'll wander around the classroom and pick up an idea.... kids will come along and say, well why aren't we doing this, why aren't we trying it that way, so we have a go and if it works it's to our pool of knowledge and if it doesn't, we scrap it (primary teacher).

While all the teachers saw themselves as learners, the knowledgebuilders had moved beyond learning technical skills from students to regaining a role as mediators of student learning. They used technology to support a range of purposes and made time to reflect on their practice with colleagues:

I think you have to really reflect on what you are doing and why you are doing it, to make it important, make it worthwhile for yourself and for the people that you are teaching. When you have made those connections and reflections for yourself, it becomes real, like someone discusses it with you, a colleague talks to you about it and you have a real sense of moving in the same direction (primary teacher).

\section{CONCLUSION}

The transition from facilitator to knowledge-builder implies that the teacher acts within a community of practice, which requires collective will and supportive leadership. Where participants take risks, reflect on experiences and share their learning, they build organisational knowledge as well as developing individual skill. The knowledge-building role was welldeveloped in the primary schools in this study, where collaborative planning, reflective journal-writing and video-conferencing were used by teaching teams. In the secondary schools teachers were experimenting with new applications of technology but were generally not reflecting systematically on their practice or their role, nor collaborating in their daily work, due in part to the pressures they perceived to meet their individual obligations of teaching a range of classes. The projects described in this paper indicate that purposeful, collaborative and supported curriculum projects provide a means of professional development for knowledge-building that can occur through teachers' daily work. 


\section{REFERENCES}

Brown, A. \& Campione, J. (1994). Guided discovery in a community of learners. In K. McGilly (Ed.), Classroom Lessons: Integrating Cognitive Theory and Classroom Practice. Cambridge, MA: MIT Press/Bradford Books.

Dwyer, D., Ringstaff, C. \& Sandholtz, J. (1991). Changes in teachers' beliefs and practices in technology-rich classrooms. Educational Leadership, 48(8), 45-53.

Hadley, M. \& Sheingold, K. (1993). Commonalities and distinctive patterns in teachers' integration of computers. American Journal of Education, 101(3), 261-315.

Hargreaves, D. (1999). The knowledge-creating school. British Journal of Educational Studies, 47(2), 122-144.

Haslam, F. (2002). The Apprenticeship Project: Practicability and Value. Paper presented at the NavCon 2K2 Conference, July, Christchurch, NZ.

Lave, J. \& Wenger, E. (1994). Situated Learning: Legitimate Peripheral Participation. Cambridge: Cambridge University Press.

Marzano, R. (1992). A Different Kind of Classroom. Alexandria, VA: Association for Supervision \& Curriculum Development.

Ravitz, J., Becker, H. \& Wong, Y. (2000). Teaching, Learning and Computing: 1998 National Survey. Report \#4. University of California, Irvine: Centre for Research on Information Technology and Organizations.

Scardamalia, M. \& Bereiter, C. (2002). Schools as knowledge building organizations. In D. Keating \& C. Hertzman (Eds), Today's Children: Tomorrow's Society: The Developmental Health and Wealth of Organizations. New York: Guildford. 